Volume 59

Issue 2 The 100th Anniversary of the Revenue

Act of 1913: Marking a Century of Income Tax

Article 4

Law in the United States

January 2015

\title{
Who Invented the Single Tax Principle?: An Essay on the History of U.S. Treaty Policy
}

REUVEN S. AVI-YONAH

Irwin I. Cohn Professor of Law at the University of Michigan

Follow this and additional works at: https://digitalcommons.nyls.edu/nyls_law_review

Part of the Taxation-Federal Commons, and the Tax Law Commons

\section{Recommended Citation}

REUVEN S. AVI-YONAH, Who Invented the Single Tax Principle?: An Essay on the History of U.S. Treaty Policy, 59 N.Y.L. SCH. L. REV. (2014-2015).

This Article is brought to you for free and open access by DigitalCommons@NYLS. It has been accepted for inclusion in NYLS Law Review by an authorized editor of DigitalCommons@NYLS. 
REUVEN S. AVI-YONAH

\section{Who Invented the Single Tax Principle?: An Essay on the History of U.S. Treaty Policy}

59 N.Y.L. Sch. L. Rev. 309 (2014-2015)

ABOUT THE AUTHOR: Reuven S. Avi-Yonah is the Irwin I. Cohn Professor of Law at the University of Michigan. He received his B.A. from Hebrew University (1983), his Ph.D. in History from Harvard University (1986), and his J.D. from Harvard Law School (1989). The author would like to thank Ann Thomas and Diane Ring for helpful comments. 
WHO INVENTED THE SINGLE TAX PRINCIPLE?

\section{INTRODUCTION}

In 1997, I wrote an article on the international tax challenges posed by the thennascent electronic commerce, in which I suggested that the international tax regime is based on two principles: the benefits principle and the single tax principle. ${ }^{1}$ The benefits principle states that active (business) income should be taxed primarily by the country of source, and passive (investment) income should be taxed primarily by the country of residence. ${ }^{2}$ This is the famous compromise reached by the four economists at the foundation of the regime in 1923 and is not particularly controversial. ${ }^{3}$ It is embodied in every one of the over 3,000 tax treaties that reduce taxation at the source of passive income while allowing source countries to tax active income if there is a permanent establishment.

The single tax principle states that cross-border income should be taxed once at the rate determined by the benefits principle. ${ }^{4}$ In other words, cross-border income should be taxed only once at the source-country rate for active income and at the residence-country rate for passive income. But if the preferred country (i.e., source for active, and residence for passive) does not tax, it is incumbent upon the other country to do so because otherwise, I argued in my article, double non-taxation would result, which is just as damaging as double taxation. ${ }^{5}$ This argument remains hugely controversial. ${ }^{6}$ While there are indications that the single tax principle was the idea underlying the adoption of the foreign tax credit by the United States in 1918, as far as tax treaties are concerned, the United States did not accept the single tax principle until more recent times. ${ }^{7}$

The United States' first tax treaty with France in 1932 reduced withholding taxes on French investors in the United States at a time when France was purely territorial and did not tax its residents' foreign source income. And as recently as 1984, the

1. Reuven S. Avi-Yonah, International Taxation of Electronic Commerce, 52 TAx L. Rev. 507, 517-23 (1997) [hereinafter Avi-Yonah, Electronic Commerce].

2. Id. at 520 .

3. See, e.g., Klaus Vogel, Double Tax Treaties and Their Interpretation, 4 Berkeley J. Int'L L. 1, 10 (1986); Bret Wells \& Cym H. Lowell, Income Tax Treaty Policy in the 21st Century: Residence vs. Source, 5 Colum. J. Tax L. 1, 6-7, 25-27 (2013). Professor G.W.J. Bruins, Professor Luigi Einaudi, Professor Edward R.A. Seligman, and Sir Josiah Stamp, four economists, reached this famous compromise. Vogel, supra, at 10 .

4. Avi-Yonah, Electronic Commerce, supra note 1, at 517.

5. Id.

6. See Mitchell A. Kane, Strategy and Cooperation in National Responses to International Tax Arbitrage, 53 Emory L.J. 89, 114-16 (2004); see also David Swenson, Global: Emerging Megatrends in Global Tax Controversy, InT'L Tax Rev. (Sept. 3, 2014), http://www.internationaltaxreview.com/Article/3376597/ Global-Emerging-megatrends-in-global-tax-controversy.html; Chris Berg, The Unspoken Benefits of Tax Avoidance, ABC News: The Drum (Sept. 23, 2014, 9:14 AM), http://www.abc.net.au/news/2014-0923/berg-the-unspoken-benefits-of-tax-avoidance/5762176.

7. See generally Michael J. Graetz \& Michael M. O'Hear, The "Original Intent" of U.S. International Taxation, 46 Duke L.J. 1021 (1997); James S. Eustice \& Thomas Brantley, Federal Income Taxation of Corporations and Shareholders 9 15.40[1] (2014). 
United States entered into a treaty with a tax haven, the Netherlands Antilles ("Antilles Treaty"), which U.S. multinationals used to borrow abroad with no withholding on the interest. ${ }^{8}$

However, in more recent times, U.S. treaty policy—and arguably domestic law as well-has changed to incorporate the single tax principle. After the United States terminated the Antilles Treaty, it not only refused to enter into additional treaties with tax havens like Singapore, but also insisted on introducing "limitation on benefits" (LOB) clauses into its existing treaties to prevent double non-taxation. Recently, the Organisation for Economic Cooperation and Development (OECD) endorsed the single tax principle as part of its Base Erosion and Profit Shifting (BEPS) project. ${ }^{9}$

In 1998, I engaged in a debate with Professor H. David Rosenbloom of New York University in which he denied both the existence of an international tax regime and the validity of the single tax principle, attacking, for example, the U.S. doubleconsolidated loss rule, which reflects that principle. ${ }^{10}$ Subsequently, other well-known tax professors like Michael Graetz, Julie Roin, and Dan Shaviro have taken Rosenbloom's position by denying the existence or utility of an international tax regime. ${ }^{11}$ Others, like Mitchell Kane and Adam Rosenzweig, have specifically critiqued the single tax principle. ${ }^{12}$ On the other hand, Yariv Brauner, Diane Ring, ${ }^{13}$ and others ${ }^{14}$ have supported my position on the single tax principle's existence in international tax law.

8. Frith Crandall, The Termination of the United States-Netherlands Antilles Tax Treaty: What Were the Costs of Ending Treaty Shopping, 9 Nw. J. Int'L L. \& Bus. 355, 356 (1998). The Antilles Treaty was subsequently terminated on June 29, 1987. Id. at 355.

9. See Public Discussion Draft of BEPS Action 6: Preventing the Granting of Treaty Benefits in Inappropriate Circumstances, OECD 2 (Mar. 14, 2014), http://www.oecd.org/ctp/treaties/treaty-abuse-discussiondraft-march-2014.pdf [hereinafter Public Discussion Draft].

10. See generally H. David Rosenbloom, International Tax Arbitrage and the "International Tax System", 53 Tax L. Rev. 137 (2000) [hereinafter Rosenbloom, International Tax Arbitrage] ("Invoking the international tax system does not constitute an explanation, since that system appears to be imaginary."). See also Reuven S. Avi-Yonah, Commentary, 53 Tax L. Rev. 167 (2000).

11. See, e.g., Michael J. Graetz, Taxing International Income: Inadequate Principles, Outdated Concepts, and Unsatisfactory Policy, 54 Tax L. Rev. 261 (2001); Julie Roin, Taxation Without Coordination, 31 J. Legal Stud. S61 (2002); Daniel N. Shaviro, Fixing U.S. International Taxation (2014), available at http://web.law.columbia.edu/sites/default/files/microsites/law-theory-workshop/files/DShaviro.pdf.

12. See, e.g., Kane, supra note 6, at 114-16; Adam H. Rosenzweig, Harnessing the Costs of International Tax Arbitrage, 26 VA. TAx Rev. 555, 588-89 (2007).

13. See Yariv Brauner, An International Tax Regime in Crystallization, 56 Tax L. Rev. 259, 291-302 (2003); Diane M. Ring, One Nation Among Many: Policy Implications of Cross-Border Tax Arbitrage, 44 B.C. L. Rev. 79, 105 (2002).

14. See, e.g., Fred B. Brown, An Equity-Based, Multilateral Approach for Sourcing Income Among Nations, 11 Fla. Tax Rev. 565, 587-95 (2011); Ehab Farah, Mandatory Arbitration of International Tax Disputes: A Solution in Search of a Problem, 9 FLA. TAx Rev. 703, 711-12 (2009); Victor Thuronyi, International Tax Cooperation and a Multilateral Treaty, 26 ВRоок. J. INT'L L. 1641, 1671-74 (2001). 
This is not just a theoretical debate among tax academics. An entire industry of tax arbitrage has arisen, which seeks to exploit differences among various countries' tax regimes in order to create double non-taxation. ${ }^{15}$ In 1997, the United States adopted the "check the box" rule, which vastly enhanced the capability of sophisticated tax lawyers to use hybrid entities as well as hybrid instruments (such as debt in one country and equity in another) to achieve double non-taxation. ${ }^{16}$ Other forms of double non-taxation result from shifting profits via transfer pricing or deductible interest, as well as royalty payments, to tax havens. ${ }^{17}$ All of these activities cost governments trillions of dollars in revenue and are condemned by the single tax principle. $^{18}$

It is therefore important to establish the historical origins of the single tax principle, which I attempt to do in the following pages. A review of the historical record shows that, in fact, it was Rosenbloom himself who gave life to what was previously a somewhat inchoate principle in the first U.S. model tax treaty, which was drafted under his own auspices as International Tax Counsel in $1981 .{ }^{19}$ The rest, as they say, is history.

The remainder of this article discusses the historical origins of the single tax principle. Section II explains the creation of the single tax principle in the context of U.S. taxation of U.S. residents from 1918 and its application to U.S. taxation of nonresidents in the treaty context from 1981 onward. Section III concludes by explaining the implications of this historical analysis to the current discussion of the single tax principle in the OECD and in the United States.

15. This phenomenon has many names— the current popular one being "stateless income"-but I prefer the old-fashioned "double non-taxation" because it resonates with the history of the regime (see below); "stateless income" is a misnomer because the income is booked in states (tax havens are fully fledged sovereign states).

16. See generally Treas. Reg. § 301.7701-2 (Westlaw 2014). See also Treas. Reg. § 301.7701-3 (Westlaw 2006). The "check the box" rule allows U.S. taxpayers, in most cases, to elect whether a foreign entity will be treated as a corporation or as a non-taxable entity by checking a box on a form attached to their tax return (e.g., a partnership or branch) for U.S. tax purposes, while keeping its character as, for example, a corporation for foreign tax purposes. This rule led to the erosion of U.S. taxation of U.S.based multinationals due to its implications for the anti-deferral and foreign tax credit rules. As a result, U.S.-based multinationals now have $\$ 2$ trillion offshore that have been subject to almost no foreign or U.S. tax, in clear violation of the single tax principle that underlay both Subpart F (I.R.C. §§ 951-965 (Westlaw 2014)) and the foreign tax credit (I.R.C. §§ 901-905 (Westlaw 2012)). IRM 4.61.5.3 (May 1, 2006), available at http://www.irs.gov/irm/index.html.

17. See generally Ernst E Young's EU Watch, 23 J. Int'L TAx'N 12, 12 (2012); Kenneth A. Grady, Income Tax Treaty Shopping: An Overview of Prevention Techniques, 5 Nw. J. Int'L L. \& Bus. 626, 628, 637 (1983).

18. See, e.g., Grady, supra note 17, at 626; John D. McKinnon, Tax Justice Network: Wealth Held in Tax Havens Skyrockets, Wall Sт. J. (July 22, 2012, 5:05 AM), http://blogs.wsj.com/washwire/2012/07/22/ tax-justice-network-wealth-held-in-tax-havens-skyrockets; The Tax Havens: The Missing \$20 Trillion, Eсоnомist, Feb. 16, 2013, available at http://www.economist.com/printedition/2013-02-16.

19. See generally H. David Rosenbloom, Caplin \& Drysdale, http://www.capdale.com/drosenbloom (last visited Jan. 25, 2015) [hereinafter Rosenbloom CV]. 


\section{THE HISTORICAL ORIGINS OF THE SINGLE TAX PRINCIPLE}

The rejection of double non-taxation under tax treaties can be traced to the first U.S. model tax treaty from 1981 ("1981 U.S. Model Tax Treaty"). ${ }^{20}$ Before that model, while the United States took steps to restrict double non-taxation of its residents, it generally permitted double non-taxation of non-residents. After 1981, the United States increasingly limited double non-taxation of non-residents, leading to the adoption of the single tax principle by the OECD. ${ }^{21}$

The single tax principle states that income should be subject to tax only once, and thus rejects both double taxation and double non-taxation. ${ }^{22}$ The rejection of double taxation was, of course, the inspiration for the entire international tax regime. ${ }^{23}$ But where does this rejection come from?

To some extent, the rejection of double non-taxation was already implicit when the United States adopted the foreign tax credit in 1918-a time when most of the other countries had exemption systems. ${ }^{24}$ The foreign tax credit ensures that income not subject to tax at source will be subject to tax by the United States as the residence jurisdiction. ${ }^{25}$ To justify the foreign tax credit, its architect, T.S. Adams, wrote, the "state which with a fine regard for the rights of the taxpayer takes pains to relieve double taxation, may fairly take measures to ensure that the person or property pays at least one tax." ${ }^{26}$ According to Adams, the exemption system should be rejected

20. See generally Treasury Department's Model Income Tax Convention of June 16, 1981, art. 23, June 16, 1981, U.S. Tax Treaties Rep. (CCH) [hereinafter 1981 U.S. Model Tax Treaty].

21. See Paul R. McDaniel et al., Introduction to United States Taxation 183 (5th ed. 2005); OeCD, Commentaries on Articles of the Model Tax Convention: Commentary on Article 197 (2010), available at http://www.oecd.org/berlin/publikationen/43324465.pdf [hereinafter OECD Commentary].

22. See Avi-Yonah, Electronic Commerce, supra note 1, at 509.

23. Id. at 517 (citing Thomas S. Adams, Interstate and International Double Taxation, in Lectures on Taxation 101 (Roswell Magill ed., 1932)).

24. See Revenue Act of 1918, ch. 18. §§ 222(a)(1), 238(a), 240(c), 40 Stat. 1057, 1073, 1080-82 (1919). See generally Graetz \& O'Hear, supra note 7. There are two accepted methods to prevent double taxation of the same income by source and residence jurisdictions: the credit system and the exemption system. Both methods have the right to tax income under international law principles of jurisdiction. See AviYonah, Electronic Commerce, supra note 1, at 519. The double taxation problem arises, for example, when A, a resident of country $\mathrm{X}$, earns $\$ 100$ of income from sources in country Y. Both country X (the residence jurisdiction) and country $Y$ (the source jurisdiction) may tax the income. Under an exemption system, $\mathrm{X}$ simply does not tax foreign source income so that the tax is levied only by country Y. Under a credit system, country $\mathrm{X}$ grants a credit of $\$ 1$ for every $\$ 1$ of tax levied by country $\mathrm{Y}$. Thus, if the $\mathrm{Y}$ rate is $30 \%$ and the $X$ rate is $35 \%$, under the exemption system, $Y$ will collect $\$ 30$ and $X$ will collect $\$ 0$. Under the credit system, $\mathrm{Y}$ will collect $\$ 30$ and $\mathrm{X}$ will collect $\$ 5(\$ 35-\$ 30)$. The main difference between the two methods arises if $Y$ does not tax at all because, under the exemption system, the total tax will be $\$ 0$ (double non-taxation), while under the credit system, the total tax will be $\$ 35$.

25. Jerold A. Friedland, Understanding International Business and Financial Transactions 342-43 (LexisNexis, 3d ed. 2010).

26. Adams, supra note 23 , at $112-13$. 
because it means that the residence country does not impose a tax regardless of whether or not the income was taxed at source. ${ }^{27}$

The first model treaty, drafted by the League of Nations Committee of Technical Experts in $1927,{ }^{28}$ explicitly acknowledged this principle in its commentary. The commentary states:

From the very outset, [the drafters of the model convention] realised the necessity of dealing with the questions of tax evasion and double taxation in co-ordination with each other. It is highly desirable that States should come to an agreement with a view to ensuring that a taxpayer shall not be taxed on the same income by a number of different countries, and it seems equally desirable that such international co-operation, should prevent certain incomes from escaping taxation altogether. The most elementary and undisputed principles of fiscal justice, therefore, required that the experts should devise a scheme whereby all incomes would be taxed once, and once only. ${ }^{29}$

However, this argument applied to the United States solely as a residence country, not as a source country. ${ }^{30}$ As a residence country, the United States adopted a foreign tax credit and not an exemption system in 1918, and also adopted the foreign personal holding company rules in 1937, to prevent double non-taxation of its residents. ${ }^{31}$ As a source country, however, our first income tax treaty concluded with France in 1932, and it reduced U.S. withholding taxes (e.g., on royalties to zero) at a time when France was purely territorial and did not tax foreign source income. ${ }^{32}$ Thus, at approximately the same time as the United States was enacting the foreign personal holding corporation provisions to ensure that its residents pay tax on income unlikely to be taxed at source, it was tolerating double non-taxation of U.S. source income earned by non-residents. ${ }^{33}$ The same tolerance applied to U.S. tax treaties, which were commonly extended to tax havens. ${ }^{34}$

The first U.S. treaty indicating that double non-taxation of U.S. source income was inappropriate was the treaty with Luxembourg, ${ }^{35}$ which precluded the application

27. See Graetz \& O'Hear, supra note 7, at 1027-28.

28. T.S. Adams was one of the drafters of the first model treaty. Report Presented by the Committee of Technical Experts on Double Taxation and Tax Evasion, League of Nations Doc. G.216.M.85 II (Apr. 1927).

29. Id. (emphasis added).

30. See generally Graetz \& O'Hear, supra note 7.

31. Id. at 1022; see also Eustice \& Brantley, supra note 7.

32. See David R. Milton, Taxing Multinationals; The States Have Made it a Nightmare, N.Y. Times, Feb. 26, 1984 , § 3, at 32, available at 1984 WLNR 447203.

33. See I.R.C. § 551, Pub. L. No. 100-647, tit. I, § 1012(bb)(1)(A), (B), 102 Stat. 3533 (Westlaw 1988), repealed by American Jobs Creation Act of 2004, Pub. L. No. 108-357, § 413, 118 Stat. 1418. See generally Graetz \& O'Hear, supra note 7.

34. See Grady, supra note 17 , at $626-31$.

35. Convention With Respect to Taxes on Income and Property, U.S.-Lux., art. XV, Dec. 18, 1962, 15 U.S.T. 2355; see H. David Rosenbloom, Tax Treaty Abuse: Policies and Issues, 15 Law \& Pol’y Int'L Bus. 763, 781 (1983) [hereinafter Rosenbloom, Tax Treaty Abuse]. 
of reduced U.S. withholding rates to certain Luxembourgian holding corporations that were not subject to tax on a residence basis. ${ }^{36}$ Similar language appears in the 1963 protocol to the Antilles Treaty. ${ }^{37}$ Interestingly, these provisions were contemporaneous with the enactment of Subpart F of the Internal Revenue Code, ${ }^{38}$ which significantly limited double non-taxation for controlled foreign corporations (CFCs) by subjecting both passive and active income not taxed at source (base company income) to current U.S. tax at residence. ${ }^{39}$ However, the scope of the Antilles Treaty provision was limited by an agreement that an Antilles company could entitle itself to treaty benefits by either electing to be subject to a low $15 \%$ tax at residence, or owning $25 \%$ of the U.S. payor. ${ }^{40}$

Similar limitations on particular types of holding companies appeared in the 1970 U.S. treaty with Finland and the 1975 U.S. treaty with Iceland. ${ }^{41}$ The 1975 U.K. treaty imposed an $\mathrm{LOB}$ on corporate residents if the tax imposed by the residence country was "substantially less" than the general corporate tax and $25 \%$ or more of the company was held by third-country residents. ${ }^{42}$ However, the limitation did not apply to U.K. close companies or to companies held by U.K. individuals, giving rise to Rosenbloom's comment that "it is difficult to discern a coherent U.K. treaty policy in the article." ${ }^{43}$ The 1978 protocol to the treaty with France likewise contained only narrow limitations. ${ }^{44}$

In general, therefore, U.S. policy before 1979 did not significantly restrict double non-taxation in regard to U.S. source income, despite placing significant unilateral

36. See Rosenbloom, Tax Treaty Abuse, supra note 35, at 781. Stanley Surrey, who also was responsible for rejecting "tax sparing" by the Senate in the context of the Pakistan treaty hearings in 1957, oversaw the Luxembourg treaty. See Stanley S. Surrey, The Pakistan Tax Treaty and "Tax Sparing", 11 NAt'L Tax J. 156 (1958). Tax sparing was rejected because it involved double non-taxation. I therefore suspect that if we investigated the unpublished Surrey papers at Harvard Law School, we would find considerable evidence that he further articulated the single tax principle, and I hope to undertake this search in the future.

37. Protocol for the Avoidance of Double Taxation and the Prevention of Fiscal Evasion With Respect to Taxes on Income and Certain Other Taxes, U.S.-Neth., art. I, Oct. 23, 1963, 15 U.S.T. 1900 [hereinafter U.S.-Neth. Protocol].

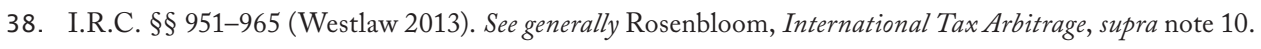

39. See Rosenbloom, International Tax Arbitrage, supra note 10, at 157.

40. See Rosenbloom, Tax Treaty Abuses, supra note 35, at 783-84; U.S.-Neth. Protocol, supra note 37, art. I(2)(a).

41. Convention for the Avoidance of Double Taxation and the Prevention of Fiscal Evasion With Respect to Taxes on Income and Capital, U.S.-Ice., art. 27, May 7, 1975, 26 U.S.T. 2004; Convention for the Avoidance of Double Taxation and Property and Prevention of Fiscal Evasion With Respect to Taxes on Income and Property, U.S.-Fin., art. 27, Mar. 6, 1970, 22 U.S.T. 40. See Richard L. Doernberg, Legislative Override of Income Tax Treaties: The Branch Profits Tax and Congressional Arrogation of Authority, 42 Tax Law. 173, 188-89 (1989).

42. Convention for the Avoidance of Double Taxation and the Prevention of Fiscal Evasion With Respect to Taxes on Income and Capital Gains, art. 16, Dec. 31, 1975, 31 U.S.T. 5668 [hereinafter U.K. Treaty].

43. Rosenbloom, Tax Treaty Abuse, supra note 35, at 790.

44. See Protocol With Respect to Taxes on Income and Property of July 28, 1967, as amended by Protocol of Oct. 12, 1970, U.S.-Fr., art. 7, Nov. 24, 1978, 30 U.S.T. 5109. 
limits on double non-taxation when the United States was the country of residence. ${ }^{45}$ However, in 1979, following congressional hearings that revealed the extensive use of the Antilles Treaty by third-country residents, the U.S. Department of the Treasury announced its intention to reexamine the Antilles Treaty and a series of treaty extensions to current and former U.K. colonies. ${ }^{46}$ In 1981, the U.S. Treasury published the new 1981 U.S. Model Tax Treaty, which, for the first time, included a broad LOB provision applicable to both corporations and individuals. ${ }^{47}$ This provision provided that the benefits of reduced withholding under the treaty will not apply to non-publicly traded corporations residing in the treaty partner, unless over $75 \%$ of such corporations are owned by individual residents and their income is not paid out to residents of third countries. ${ }^{48}$ Additionally, the LOB provided that treaty benefits will not be available to corporations entitled to a significantly lower tax rate in their country of residence. ${ }^{49}$ Subsequent to the 1981 U.S. Model Tax Treaty, the LOB provision became a standard part of all U.S. treaties. ${ }^{50}$ Indeed, ever since the

45. See U.K. Treaty, supra note 42, art. 16.

46. U.S. Dep't of the Treasury, Annual Report of the Secretary of the Treasury on the State of the Finances 58 (1979).

47. See 1981 U.S. Model Tax Treaty, supra note 20, art. 16.

48. $I d$.

49. The provision states:

1. A person (other than an individual) which is a resident of a Contracting State shall not be entitled under this Convention to relief from taxation in the other Contracting State unless

(a) more than 75 percent of the beneficial interest in such person is owned, directly or indirectly, by one or more individual residents of the first-mentioned Contracting State; and

(b) the income of such person is not used in substantial part, directly or indirectly, to meet liabilities (including liabilities for interest or royalties) to persons who are residents of a State other than a Contracting State and who are not citizens of the United States.

For the purposes of subparagraph (a), a company that has substantial trading in its stock on a recognized exchange in a Contracting State is presumed to be owned by individual residents of that Contracting State.

2. Paragraph 1 shall not apply if it is determined that the acquisition or maintenance of such person and the conduct of its operations did not have as a principal purpose obtaining benefits under the Convention.

3. Any relief from tax provided by a Contracting State to a resident of the other Contracting State under the Convention shall be inapplicable to the extent that, under the law in force in that other State, the income to which the relief relates bears significantly lower tax than similar income arising within that other State derived by residents of that other State.

Id.

50. The LOB provision was first included in the treaties with Jamaica (1980), New Zealand (1982), Australia (1982), Denmark (1983), France (1984), Cyprus (1984), and every subsequent U.S. treaty. See Convention for the Avoidance of Double Taxation and the Prevention of Fiscal Evasion With Respect to Taxes on Income, U.S.-Jam., arts. 17, 24, May 21, 1980, 33 U.S.T. 2865 (1981); Convention for the 
Senate in 1981 refused to ratify the treaty with Argentina unless it included an LOB, it has been clear that no U.S. treaty will be ratified without an LOB. And in 1986, Congress created a treaty override by adopting a "qualified resident" test (a simple LOB) in the context of the branch profits tax, which made it applicable to all U.S. treaties, including the majority that did not yet have an LOB provision. ${ }^{51}$

Some argue that the creation of the LOB provision had nothing to do with double taxation, but was meant to prevent the United States from having a "treaty with the world" (i.e., allowing any non-resident to achieve treaty benefits without residing in a treaty jurisdiction) by restricting treaty benefits to residents of that state and not allowing the extension of benefits to residents of other states, regardless of whether they were subject to tax at residence. ${ }^{52}$ This, it can be argued, was also the purpose of terminating the treaties with the Antilles and other tax havens in 1987.53

But this view of the purpose of the LOB provision is inconsistent with the last paragraph of the 1981 model LOB, which explicitly makes the reduction of sourcebased taxation contingent on taxation at residence without regard to the ownership of the recipient of the income. ${ }^{54}$ It is also inconsistent with the contemporaneous views held by Rosenbloom who, as International Tax Counsel from 1977 to 1981, was responsible for the inclusion of the LOB provision in the 1981 U.S. Model Tax Treaty and other treaties of that period..$^{55}$ In an article published in 1983, Rosenbloom explained the policy behind the LOB provision:

Many commentators believe that existing international commerce is, to a considerable extent, structured on the assumption that liberal use of treaties will be tolerated .... The fundamental goal of tax treaties is removal of the negative effects of double taxation .... Since treaties are intended to eliminate double taxation, their benefits should flow to persons who, in the absence of the treaty, might be subject to double taxation. These are persons who, while potentially subject to tax in one country on either a source or a personal basis, are also subject to tax in the other country on a personal basis. A principal

Avoidance of Double Taxation and the Prevention of Fiscal Evasion With Respect to Taxes on Income, U.S.-N.Z., art. 4(1), July 23, 1982, S. Treaty Doc. No. 92-27; Convention for the Avoidance of Double Taxation and the Prevention of Fiscal Evasion With Respect to Taxes on Income, U.S.-Austl., art. 16, Aug. 6, 1982, S. Treaty Doc. No. 97-28; Protocol to Amend 1980 Tax Convention, U.S.Den., art. 8, Aug. 23, 1983, S. Treaty Doc. No. 98-12; Protocol on Double Taxation With Respect to Taxes on Income and Property, U.S.-Fr., art. 12, Jan. 17, 1984, T.I.A.S. No. 11096; Convention for the Avoidance of Double Taxation and the Prevention of Fiscal Evasion With Respect to Taxes on Income, U.S.-Cyprus, art. 26, Mar. 19, 1984, S. Treaty Doc. No. 98-32.

51. See Richard Andersen, Analysis of United States Income Tax Treaties, 1 1.03(a)(iii); I.R.C. § 884 (Westlaw 2007); Treas. Reg. § 1.884-0 (Westlaw 2008); see also I.R.C. § 7701(1) (Westlaw 2010) (overriding all U.S. treaties to impose a conduit financing test inspired by Aiken Indus., Inc. v. Comm'r, 56 T.C. 925 (Westlaw 1971)).

52. See McDaniel et al., supra note 21, at 183.

53. The United States terminated its income tax treaties with Aden and a group of other U.K. colonies: Aruba, Netherlands Antilles, Belgian Congo, Honduras, Malawi, and Nicaragua.

54. 1981 U.S. Model Tax Treaty, supra note 20, art. 16, ๆ 3.

55. See id. art. 16; Rosenbloom CV, supra note 19. 
WHO INVENTED THE SINGLE TAX PRINCIPLE?

task of treaty drafters, then, should be to identify those persons in each country who are subject to that country's personal taxing jurisdiction . . . . It may prove necessary in some cases to adopt special rules to ensure that taxation on a personal basis is not avoided altogether. ${ }^{56}$

While Rosenbloom later mentioned the "treaty with the world" problem and the revenue impact of allowing third-country investors to benefit from a treaty, the principal thrust of these observations is that the United States (as a source jurisdiction) should not reduce its withholding tax, unless it has some reasonable assurance that the income will be subject to tax on a residence basis. ${ }^{57}$

By 1981, the single tax principle had become a foundation block of U.S. international tax policy. This is evidenced by the combination of the foreign tax credit and Subpart F, which seeks to ensure that active income residence-based taxation will apply when there is no tax at the source, and the LOB provision, which seeks to ensure that passive income source-based taxation will apply when there is no tax at residence. ${ }^{58}$ As Rosenbloom stated, "One possible course would be for Country $\mathrm{X}$ not to enter into a treaty relationship unless it is satisfied that State $\mathrm{Y}$ will be likely to impose a full tax on all persons falling within the personal jurisdiction of State Y. In theory, then, at least a single, substantial tax will be collected." ${ }^{59}$

\section{CONCLUSION}

Although the single tax principle remains controversial, LOB provisions have proliferated, and starting in the early twenty-first century, the OECD adopted the single tax principle as part of its model treaty. ${ }^{60}$ The OECD model treaty's commentary on Article 1 contains both a full-fledged LOB provision and a discussion of partnerships and other entities not subject to tax, which are excluded from the scope of the substantive articles. ${ }^{61}$ According to the OECD view, these provisions apply to any tax treaty that contains the language of Article 1 , which is every tax treaty (regardless of whether it was negotiated before or after the changes to the commentary were adopted)..$^{62}$

Thus, the key date for the creation of the single tax principle was 1981. Until 1979, the United States encouraged using the Antilles Treaty to enable U.S. corporations to borrow overseas without imposing withholding tax on the interest. ${ }^{63}$ This former practice is similar to the current policy of India, which seeks to avoid

56. Rosenbloom, Tax Treaty Abuse, supra note 35, at 764-73.

57. Id. at $774-75$.

58. See I.R.C. §§ 901-909 (Westlaw 2012); id. §§ 951-965 (Westlaw 2013).

59. Rosenbloom, Tax Treaty Abuse, supra note 35, at 776 (emphasis added).

60. See generally OECD Model Convention for the Avoidance of Double Taxation With Respect to Taxes on Income and on Capital, 2005, U.S. Tax Treaties Rep. (CCH).

61. OECD Commentary, supra note 21, ๆף 1-4 (2010).

62. Id. \21.5.

63. McDaniel et Al., supra note 21, at 183. 
double taxation. ${ }^{64}$ Hong Kong may fulfill a similar role for China, Cyprus for Russia, and the Netherlands for Brazil. ${ }^{65}$

The United States stopped implementing this policy in $1981 ;{ }^{66}$ the cessation of this policy created a huge gap in the single tax principle. In 1984, the United States enacted the portfolio interest exemption, which resulted in adverse consequences for developing countries and the United States' own ability to tax its residents on worldwide income. ${ }^{67}$ The repercussions of this portfolio interest exemption are still present today. ${ }^{68}$ However, this gap in the single tax principle may be closed if the emerging network of intergovernmental agreements under the Foreign Account Tax Compliance Act leads to a genuine automatic exchange of information. There are also signs that even the BRICS countries ${ }^{69}$ are reconsidering, with Brazil for example, imposing a tax on payments to tax havens. ${ }^{70}$ The next step may be the introduction of an LOB provision into the OECD model itself, in addition to the commentary. Another step may be the incorporation of the single tax principle into the BEPS proposals to combat the abuse of both hybrid instruments and hybrid entities. ${ }^{71}$ The single tax principle has come to stay.

64. See Joe Dalton, Tax Disputes: The Cases to Look Out For in 2013, 23 Int'l Tax Rev. 28, 28-29 (20122013); K.R. Girish, Delhi High Court Blocks Mauritius Tax Relief, 13 Int'l Tax Rev. 35, 35-36 (2002).

65. See generally Dylan Sutherland et a1., An Exploration of How Chinese Companies Use Tax Havens and Offshore Financial Centres: 'Round-Tripping' or 'Capital-Augmenting' ODFI?, (Univ. of Oxford Dep't of Int'l Dev., Working Paper No. 042); Liz Alderman, Russians Return to Cyprus, a Favorite Tax Haven, N.Y. Times (Feb. 17, 2014), http://www.nytimes.com/2014/02/18/business/international/russianbusiness-target-of-cypriot-bailout-still-loves-theisland.html?_r=0; Simon Goodley \& Dan Milmo, Dutch Masters of Tax Avoidance, Guardian (Oct. 19, 2011, 2:26 PM), http://www.theguardian.com/ business/2011/oct/19/tax-avoidance-in-netherlands-becomes-focus-of-campaigners. See also Convention for the Avoidance of Double Taxation and the Prevention of Fiscal Evasion With Respect to Taxes on Income, Neth.-Braz. Jan. 1, 1992, available at http://www.receita.fazenda.gov.br/principal/ ingles/Acordo/Netherlands/Netherlands08031990.htm.

66. See Crandall, supra note 8, at 363-65 (discussing the United States' efforts to eliminate treaty shopping).

67. Toby Cozart, Structuring Foreign Investments in U.S. Corporations Using Portfolio Debt Guaranteed by the Issuer's Foreign Affiliate, 6 Berkley J. Int'L L. 398, 405-16 (1988). See generally Patrick W. Martin \& Pedro E. Corona de la Fuente, Overview of U.S. Interest Income, Exempt From U.S. Income Taxation for the Foreign Investor ("Portfolio Interest"), Procopio (Feb. 2011), http://www.procopio.com/userfiles/file/ assets/files1/overview-of-u-s-interest-income-exempt-from-u-s-income-taxation-for-the-foreigninvestor-portfolio-interest-900-pdf1-900.pdf.

68. See generally Brian K. Jordan, Business and Tax Planning with the Portfolio Interest Exemption, 73 FLA. B. J. 52 (1999).

69. The BRICS countries refer to the five emerging national economies: Brazil, Russia, India, China, and South Africa. Leo Panitch, The US Still Decides the Future of Capitalism, Not the G2O, and Not the BRICS Nations, Guardian (Aug. 27, 2014, 1:43 PM), http://www.theguardian.com/commentisfree/2014/ aug/27/the-us-still-decides-the-future-of-capitalism-not-the-g20-and-not-the-brics-nations.

70. Andrea Bazzo Lauletta et al., Brazil Publishes Its Black and Greylists, 21 Int'L Tax Rev. 72, 72 (2010).

71. Hugh Ault, who is a major influence on the BEPS endeavor, cites the single tax principle in the beginning of his recent article on BEPS. See Hugh J. Ault, Some Reflections on the OECD and the Sources of International Tax Principles, 70 Tax Notes Int'l 1195, 1195 (2013); see also Public Discussion Draft, supra note 9, at 2 (discussing steps to prevent the granting of treaty benefits in inappropriate circumstances). 